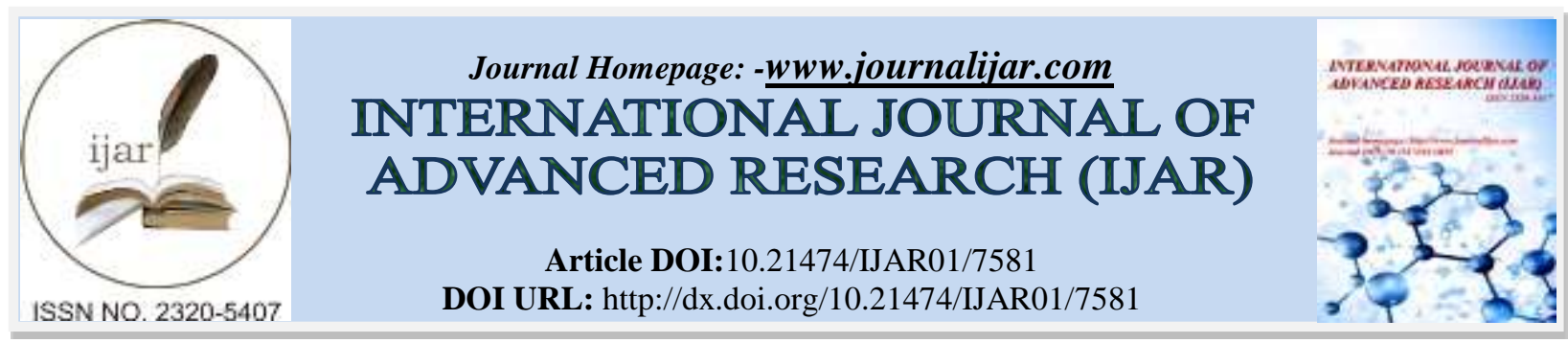

RESEARCH ARTICLE

\title{
COMPARISON OF THE EFFCINEY OF SOME MOUTH WASHES FROM DIFFERENT ORIGINS AGAINST LACTOBACILLUS AND STREPTOCOCCUS MUTANS THAT ISOLATED FROM GINGIVITIS \&DENTAL CARIES.
}

\author{
Angham J. A. Al-Oqaidy ${ }^{1}$, Mohammed S. E. AL-saffar ${ }^{2}$ and Nada J. A. Al-Oqaidy ${ }^{1}$. \\ 1. Department of Biology, College of Science,University of Mosul . \\ 2. General dentist, Ministry of Health, Nineveh Health Department.
}

\section{Manuscript Info}

Manuscript History

Received: 17 June 2018

Final Accepted: 19 July 2018

Published: August 2018

Keywords:-

Mouthwash, antimicrobial activity, Streptococcus, Lactobacillus, gingivitis, dental caries.

\begin{abstract}
The study include isolation and diagnosis of Streptococcus mutans and Lactobacillus spp. Which cause gingivitis and dental caries and culturing on Mitis Salivarius Agar media for Streptococcus mutans and cultring Lactobacillus on (MSR).

(30) sample was taken from patients suffering gingivitis and dental caries by paper point and transferred to laboratory by transporting media and (MSR),(MSA) and incubated in unarobic condition under (37)for 72 hours.

The result aeal that Streptococcus mutans(9) samples and its ratio $(56.25 \%)$, while of (7) samples the bacteria Lactobacillus and its ratio $(43.75 \%)$.

Comparis of (8) types of mouth washes from different origin in as listid(1) and there effects on isolated bacteria.
\end{abstract}

Copy Right, IJAR, 2018,. All rights reserved.

\section{Introduction:-}

In the different sites of the mouth, the bacteria are able of cohabiting in saprophytism, depending directly on many factors such as $\mathrm{pH}$, availability of nutrients and natural of mucous surface. The establishment and maintenance of oral microbiota is related to inter bacterial co aggregation and biofilm formation, which constitute the primary etiologic agents of oral diseases(Tanzer,et al .,2001 ). The plaque (biofilm)related infection such as dental caries and Periodontal disease represent two most common types of dental disease. The dental plaque provides ground for the inhabitancy of pathogenic bacteria that lead to the tooth decay, where bacterial processes change sugar in food left on tooth to acid that demineralization hard tooth structure from calcium and progressively break down(Prashant, et al .,2007).

The demineralization which caused particularly by Streptococcus bacteria occurs within dental plaque that adheres to the tooth surfaces and become colonized by other bacteria such as Lactobaciccussp, some species of gram negative bacteria, yeas and that responsible to secondary infection in mouths (Gamal,M.E.S.,2014).

Dental caries is a multifactorial disease. A number of lifestyle, environmental andhereditary factors contribute to its development. These include the frequent intake offermentable carbohydrates, poor oral hygiene, high counts of cariogenicmicroorganisms, the inadequate use of fluoride and impaired salivary function (Koneman,et al .2006).mutans streptococci are considered majorpathogens in the initiation of caries due to their acidogenic and 
aciduric properties andtheir ability to adhere to the tooth surface and to other bacteria (6-8). Lactobacilli, which are highly acidogenic, are more common in deep caries lesions and indicatehigh fermentable carbohydrate consumption and disease progression rather thaninitiation (Taciano,et al .,2010).

There are several types of mouth wash which all perform aparticular function . there are mouth washes which help to sterngthen your teeth, antiseptic mouthwashes which deal with tooth decay and hide bad breath and herbal mouthwashes which do not contain alcohol.

The types of mouthwash available include :

1. Fluoride mouthwashes contain sodium floride which helps to strengthen the teeth as well as adding extra protection against tooth decay . however ,fluoride is present in toothpaste and tap water and is more than adequate for our needs.Be careful about consuming excessive amounts of fluoride.

2. cosmetic mouthwashes do not offer the same protection as other types and are used more as ameans of disguising bad breath (halitosis).they help to keep your teeth clean but don't reduce the risk of tooth decay.

3. antiseptic mouthwashes contain chlorhexidine gluconate_achemical which stops the growth of bacteria and is suitable for peopale with bad breath (halitosis)

4. They are effective in that they can prevent the build up of plaque to certain degree but they should be used in conjuction with atoothbrush and dental floss .

5. Avoid overuse of these as the high level of chlorohexidine can cause discolouration of teeth over along period of time .but if you don't experience this then your dentist or dental hygienist will be able to easy treat it.

6. .natural mouthwashes are alcohol free (and contain no floride) and work in much the same way as conventional mouthwashes.

7. Some people find that ahome -made mouth wash , such as those made from apinch of salt and warm water ,are useful following a tooth extraction .they can also treat amouth infection or injery.

8. .total care mouthwashes contain antibacterial ingrediant which help to reduce the build up of plaque and prevent gum disease.(Deman, etal.,1960; Cochran,2009; Conneally,2010)

9. So the purpose of this study was aimed to isolate and identify of oral pathogenic bacteria from patient suffering from gingivitis and dental carrier and make a comparison between the effect of antibacterial activity of eight types of mouthwashes from diffirent origin on these bacteria and the formation of biofilm.

10. The purpose of this study was to examine the bactericidal activity of selected herbal products and other products for mouth washing, possessing antibacterial activity as declared by the manufacturers, used in treatment of inflammation and for disinfection of the mouth.

\section{Materials \& Methods:-}

\section{1-Specimens collection and bacterial identification:}

thirty swabs were obtained from patients clinically diagnosed by dental physicians to have gingivitis and dental carrier.The infected area of the tooth was swabbed with sterile cotton wool andtransferred to a sterile screw cappedtube that contained $5.0 \mathrm{ml}$ of Reduced.

Transport Fluid (RTF) with aseptic The swabs were streaked on general and selective media MRS (deMan Rogoza Sharpe agar ) Lactobacillus,MSA(Mitis salivarius agar)Streptococcus mutans, The plates were incubated at $37^{\circ} \mathrm{C}$ for $36-72 \mathrm{~h}$ inthe presence of 5\% $\mathrm{CO} 2$. and the number of colonies was counted based on the colony characteristics and confirmed by gram staining.(Collee,et al.,1996;Bwron,2005).

\section{Mouthwashes collection}

Eight mouthwashes products (table 1) fromMousl (Iraq) pharmacies were used in this study

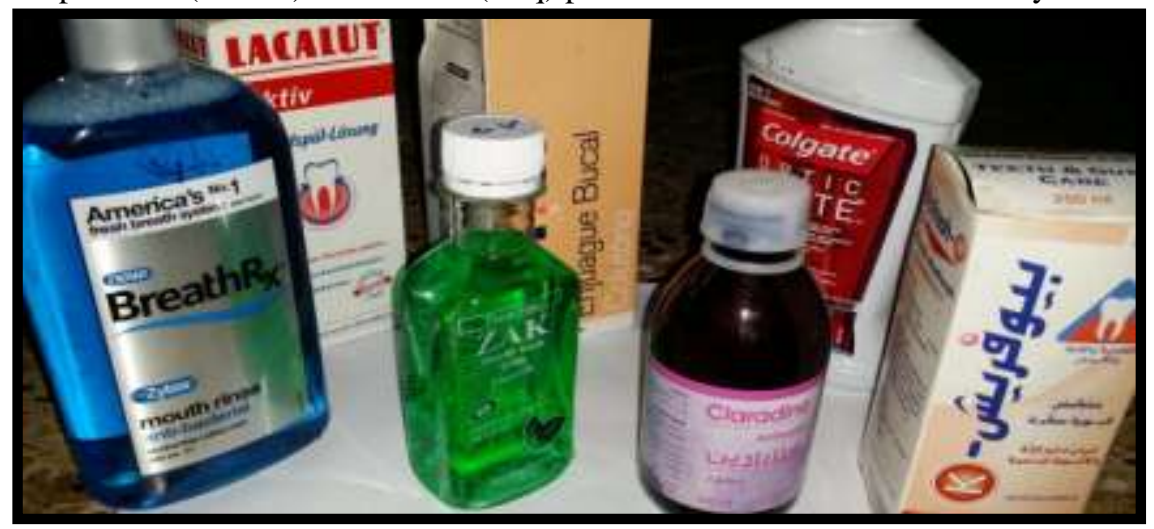


Table 1:-Types, compositions and manufacturer of the mouthwashes used in this study

\begin{tabular}{|c|c|c|}
\hline Name & Composition & Manufacture \\
\hline Clardine & Chlorhexidinedigluconate B.P 0.2 gm & United Arab Emirates \\
\hline Biofresh(K) & $\begin{array}{l}\text { Chlorhexidinegluconate } 0.12 \% \text {, Sodium saccharin, , Sorbitol,Aroma, } \\
\text { Aqua, polyoxcetelaen glycol. }\end{array}$ & Syria \\
\hline Zac & Chlorhexidinegluconate $0.12 \%$, Sodium fluoride $0.05 \%$ & Amman-Jorden \\
\hline Colgate & 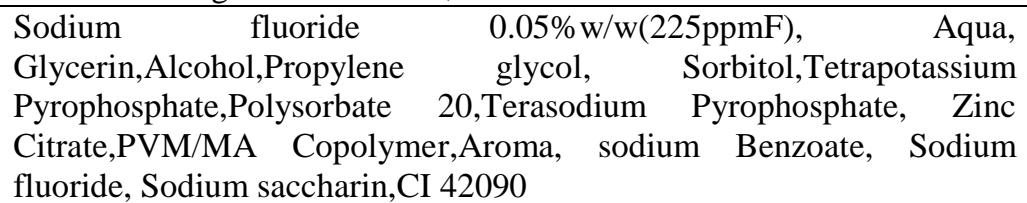 & Sao Paulo-Brazil \\
\hline Kin B5 & 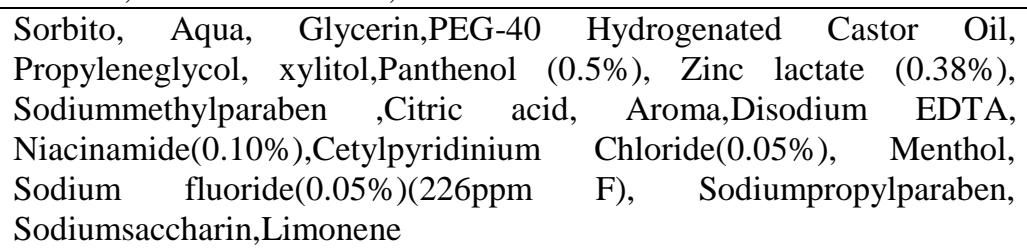 & Barcelona-Spain \\
\hline Breath RX & $\begin{array}{l}\text { Sorbitol, propylene glycol,PEG-40 Hydrogenated } \\
\text { Oil,Poloxamer407, xylitol,zinc glyconate, Aroma (mint, } \\
\text { thymol, eucalyptus oil) ,CocamidopropylBetaine, sodium } \\
\text { cetylpyridinum chloride, Citric acid,Cl42090 }\end{array}$ & $\begin{array}{l}\text { United State of } \\
\text { America }\end{array}$ \\
\hline $\begin{array}{l}\text { LACALUT } \\
\text { aktiv }\end{array}$ & $\begin{array}{l}\text { Aqua, Glycerin,PEG-40 Hydrogenated Castor Oil,Olafur, , Aroma, } \\
\text { Aluminum,Lactate, } \\
\text { Sulfate,ChlorhexidineDigluconate,PotassiumAcesulfame, } \\
\begin{array}{l}\text { Propyleneglycol, } \\
\text { hydroxyethyloctadecylamine-dihydrofluoride Fluoride } 225 \mathrm{ppm}\end{array} \\
\end{array}$ & Germany \\
\hline Water\& Saline & $\operatorname{Nacl}(500 \mu)$ & Iraq \\
\hline
\end{tabular}

\section{Bacteria Sensitivity test of mouthwash.}

Sensitivity test bacteria against mothwash table (1) to the method Bauer- Kirby on Muller-Hinton agar mediawas done by disc diffusion method. For anaerobicgrowth the plates were incubated at 37 degree $\mathrm{C}$ in anaerobic jarpresence of 5\% CO2 for 18-24 hrs and then plates wereexamined for a zone of inhibition.( Bauer,1966; Vadepitt et al.,2003).

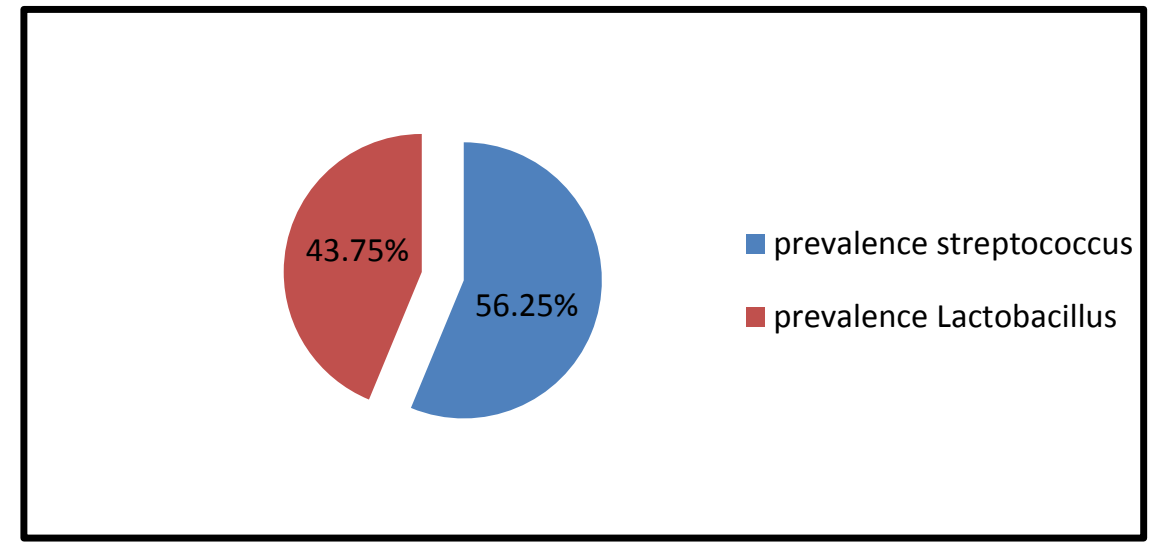

Figer:1 Ratio of bacteria isolated from dental caries

The figure (1) show the number of total samples that taken in this study and it's( 30 )in numbers from patients suffer from caries and gingivitis at different ages \&geneder.

The ratio of Streptococcus mutans is $(56.25 \%)$ while the ratio of Lactobacillus is $(43.75 \%)$ and this differentiation. 
belong to presence of these bacteria in the mouth as normal flora but with decrease in the immunity, which convert to pathological microorganism and cause gingivitis\&dental caries in presence of other factors like acidic PH, food debris and dental plaque.This specific types colonization of Streptococcus mutanscolonize dentalsurface and cause damage to hard tooth structure in the prescence of fermentable carbohydrate e.g sucrose and fructose .

\section{Results \& Discussion:-}

Table 2:-Effect of various mouthwashes on the growth of Streptococcus mutans

\begin{tabular}{|l|l|l|l|l|l|l|l|l|}
\hline \multicolumn{2}{|l|}{ Effect of mouthwashes } & \multicolumn{1}{l|}{ Samples } \\
\cline { 1 - 8 } $\begin{array}{l}\text { Water\& } \\
\text { Saline }\end{array}$ & $\begin{array}{l}\text { LACALUT } \\
\text { aktiv }\end{array}$ & $\begin{array}{l}\text { Breath } \\
\text { RX }\end{array}$ & $\begin{array}{l}\text { Kin } \\
\text { B5 }\end{array}$ & Colgate & Zac & Biofresh(K) & Clardine & Ber \\
\hline 6 & 6 & 6 & 6 & 6 & 6 & 6 & 6 & 1 \\
\hline 6 & 10 & 8 & 6 & 6 & 6 & 6 & 10 & 2 \\
\hline 6 & 9 & 6 & 6 & 6 & 6 & 6 & 9 & 3 \\
\hline 6 & 8 & 6 & 6 & 6 & 6 & 6 & 9 & 4 \\
\hline 9 & 14 & 10 & 12 & 6 & 11 & 6 & 9 & 5 \\
\hline 9 & 12 & 6 & 6 & 6 & 6 & 6 & 10 & 6 \\
\hline 9 & 10 & 6 & 6 & 6 & 6 & 6 & 10 & 7 \\
\hline 6 & 6 & 6 & 6 & 6 & 6 & 6 & 9 & 8 \\
\hline 6 & 6 & 6 & 6 & 6 & 6 & 6 & 9 & 9 \\
\hline
\end{tabular}

The table(2) show the effect of mouth washes and normal saline on bacteria Streptococcus mutans that is isolated from patients who suffer from dental caries and gingivitis.

(9) sample of isolated bacteria Streptococcus mutans used to show the effect of these mouth washes which used by dentist and the result are differ according to pathogenicity of bacteria and type of mouth wash which used the Lacalut active dental mouth wash with Germanic manufacturer show the bast effect from the other types of used mouth washes because the prescence of effective components of this mouth wash like , chlorhexidinedigluconate,propylene,glycol,limonene(hydroxyethyl) ,amino propoyl-N-hydroxyethyloctadecyl amine-dihydroflaride,fluoride $225 \mathrm{ppm}$ which regards asanti carogenicty effects .

Table 3:-Effect of various mouthwashes on the growth of Lactobacillus

\begin{tabular}{|c|c|c|c|c|c|c|c|c|}
\hline \multicolumn{8}{|c|}{ Effect of mouthwashes } & \multirow{2}{*}{$\begin{array}{l}\text { Samples } \\
\text { Number }\end{array}$} \\
\hline $\begin{array}{r}\text { Water\& } \\
\text { Saline }\end{array}$ & $\begin{array}{r}\text { LACALUT } \\
\text { aktiv }\end{array}$ & $\begin{array}{r}\text { Breath } \\
\text { RX }\end{array}$ & $\begin{array}{r}\text { Kin } \\
\text { B5 }\end{array}$ & Colgate & Zac & $\operatorname{Biofresh}(\mathrm{K})$ & Clardine & \\
\hline 6 & 9 & 6 & 6 & 6 & 6 & 6 & 9 & 1 \\
\hline 10 & 14 & 9 & 10 & 9 & 12 & 7 & 9 & 2 \\
\hline 9 & 14 & 12 & 14 & 6 & 6 & 6 & 9 & 3 \\
\hline 6 & 14 & 14 & 10 & 9 & 10 & 12 & 25 & 4 \\
\hline 9 & 6 & 6 & 12 & 6 & 6 & 6 & 9 & 5 \\
\hline 9 & 12 & 6 & 6 & 6 & 6 & 6 & 6 & 6 \\
\hline 9 & 12 & 6 & 6 & 6 & 6 & 6 & 6 & 7 \\
\hline
\end{tabular}

Then (Clardine) mouth wash with (UAE) manufacturerbecause content of chlorhexidine, digluconate $\mathrm{ppm}(0.2) \mathrm{gm}$. Then the effect of (Breath RX)mouth wash with (USA)manufacturer with limited effectiveness on the bacteria that is used in this study because it ,not contained chlorhexidine which regards bacteriostatic agent and treat gingivitis .

It noted from the results that isolation No.(5) of bacteriaStreptococcus mutansmost of mouth washes used had an effect on that isolation and this indicate the sensitivity of this isolation toward these mouth washes.

The effect of (Biofresh-K-) mouth wash and (Colgate)mouth wash on this isolation was not shown due to the components and properties of each mouth wash ,the( Biofresh-K-) contain only $0.12 \%$ chlorhexidinegulconate which is not enough to work on this bacteria and the (Colgate)mouth wash not contain chlorhexidinedigluconate and only contain $0.05 \%$ ) sodium fluoride . 
Result reveal that the normal Saline which used frequenty by dentist it very weak and it had no effect or little on the isolates under study the reasor back to lower the proportion of sodium chloride $\mathrm{NaCl}$ with $0.05 \mu$

Results proof that common mouthwash solutions havevariable antibacterial activity depending on their major active components.

Only mouthwash solutions containing chlorohexidinegluconate or cetylpyridinum chloride exhibited activity against majority,but not all tested bacterial strains in their biofilm state.

Additionally,bacteria are generally less susceptible to all mouthwash Results of this study show that mouthwash solutionpossesses variableantibacterial activity depending on theirchemical composition. For example, mouthwash solutionscontaining the antiseptics chlorhexidine are effective onmost oral bacterial strains. This correlates with previous studies and is related to chlorohexidine's mode of action asit works on different sites of the bacteria(Gamal,M.E.S.,2014;Tanzer et al.,2001). Additionally,mouthwash solutions containing sodium bicarbonate $2 \%$ were shown to be effective against most of the testedsolutions in their biofilm as compared to planktonic state. bacterial strains, which is in agreement of previous studies(Atlas,R.M.1995). 

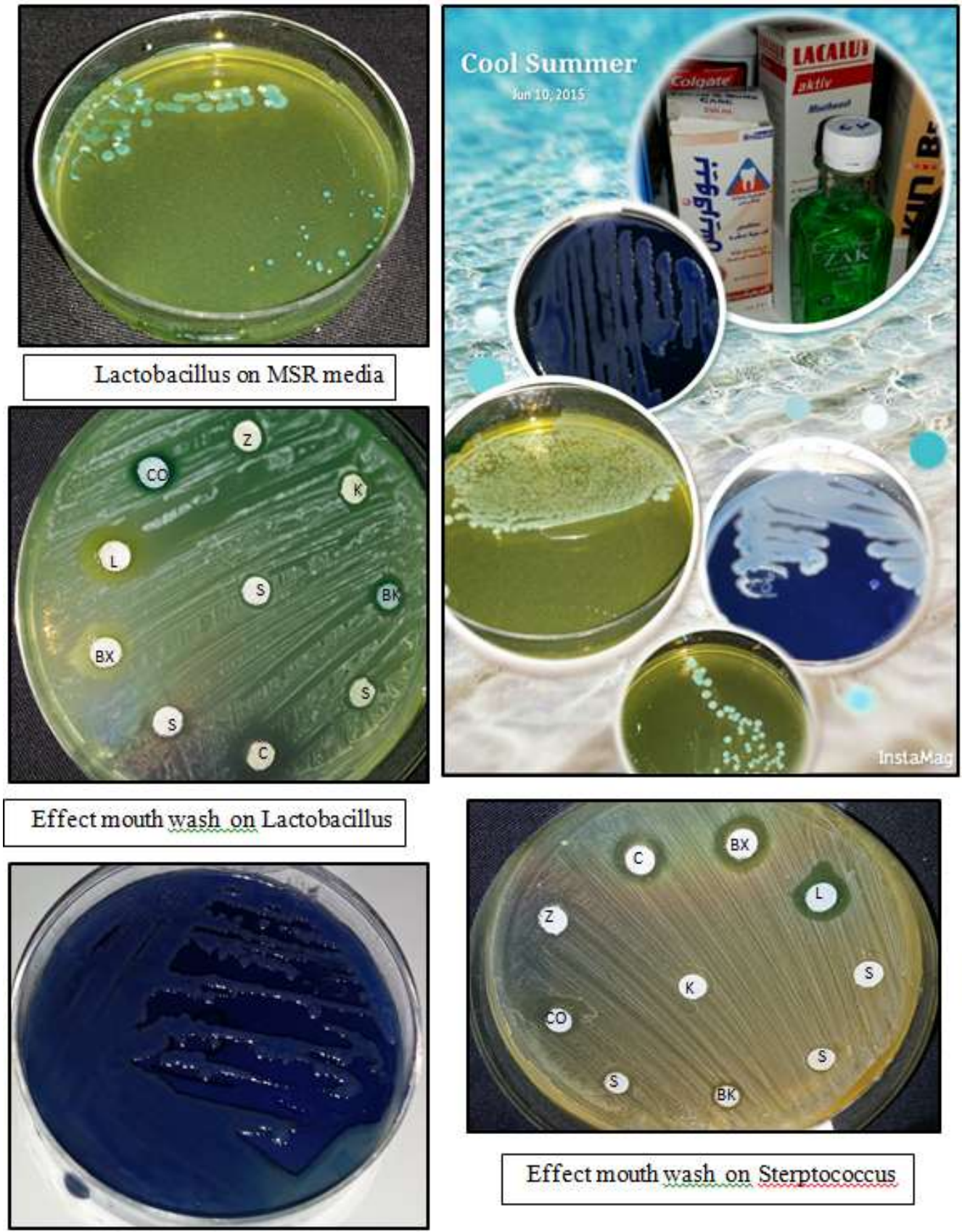

Effect mouth wash on Sterptococcus

Sterptococcus mutans on MSA

On the other hand, mouthwash solutions containingother ingredients such as cetylpyridinium chloride, sodiumfluoride, hexetidine, povidone-iodine, eucalyptol, menthol,methylsalicylate, and thymol showed activity against somebacterial strains, but not others. For example, cetylpyridiniumchloride $(0.05 \%)$ mouthwash was shown to possess antimicrobialactivity against all tested bacterial strains except $P$. aeruginosaand $K$. pneumoniae. In fact, cetylpyridinumchloride is a quaternary ammonium compound known for itsuse as a cationic surface active agent that has antibacterialactivity (Hoit, et al., 2001) Moreover, the MIC values for cetylpyridiniumchloride $(0.05 \%)$ mouthwash suggest that it has highactivity against $\mathrm{S}$. aureus. This is in agreement with previouslypublishedwork on cetylpyridinium chloride products. 


\section{References:-}

1. Tanzer, J.M. , Livingston, J. and Thompson, A.M. "Microbiology ofprimary dental caries in humans". J Dent Educ.(2001) 65(10):1028-1037.

2. Prashant GM, Chandu GN, MurulikrishnaKS,Shafiulla MD. The effect of mango and neem extracton four organisms causing dental caries: Streptococcusmutans, Streptococcus salivavius, Streptococcus mitis, and Streptococcus sanguis: An in vitro study. Indian J .Dent Res( 2007) 18(4): 148-151. (IVSL).

3. Gamal M. El-Sherbiny. Control of growth Streptococcus mutans isolated from saliva and dental caries, Int.J.Curr.Microbiol.App.Sci (2014) 3(10) 1-10.

4. Koneman, E.W., AIlen, S.D., Janda, W.M., Schrecken, Berger, P.C. and Jr, W.C.W. Color Atlas and Text Book of Diagnostic Microbiology. 6rd Ed. J.B.Lippincott Comp., Philadelphia USA.,(2006) pp. 335-355.

5. Taciano RC, Alexandre SC, Marcelo E B, Marcelo H .N and Geraldo T J. Metabolic activity ofStreptococcus mutans biofilms after treatment with 2010(1): 74-78.Cochran, Sylvia ,Publishes Study Linking Mouthwash to cancerntal Journal of Australia,Jan.12,(2009).

6. Cochran , Sylvia ,Publishes Study Linking Mouthwash to cancer ,ntal Journal of Australia,Jan.12,(2009).

7. Conneally, Paul, Mouthwash cancer risk ,Dental Journal of AusDetralia,Jan.10,(2010) .

8. Collee, J.G.; Fraser, A.G.; Marmion, B.P. \& Simmons, A. Mackie \&MeCartneypractical Medical Microbiology. 14th ed., Churchill Living stone, U.S.A. (1996).

9. Brown, A.F. "Benson's Microbiological applications". LaboratoryManual in General Microbiology .9th ed . McGraw-Hill. New York.USA. (2005).

10. Bauer, A.W .; Kirby, W.M . ; Sherris , J.c. and Turch . A. Antibiotic susceptibility testing by standardised single disk method, W.M. Ameri.J.clin . pathol.(1966) $45: 493$.

11. Vadepitte, A andBalows .,J . Berch -Level procedure manual on basic bacteriology . W.H.O. / Lab / (2003) 87.1.

12. Holt, J.; Krieg, N.; Sneath, P.; Staley, J.; Williams, S. Bergey's manual of determinative bacteriology, 9th ed.; Williams \& Wilkins: Baltimore, MA, USA, 1994.

13. Atlas, R.M. Principles of Microbiology. Mosby. Comp.different mouthwash formulations. Braz J Oral Sci.(1995)10(1): 74-78.

14. AL-Dabbagh, W., Al-Mallah, M. and AL-Regab, W. Effect of Some Tothe Pastes on Lactobacilli in Mouth. Iraq. Med. Dies,(1982) Vol. 24, 1 p. 